\title{
Social capital, 'trust' and the role of networks in Julfan trade: informal and semi-formal institutions at work
}

\author{
Sebouh Aslanian \\ Columbia University, Department of Middle East and Asian Languages and Culture, \\ 602 Kent Hall, 2960 Broadway, New York, NY 10027-6902, USA \\ E-mail: Elixe@aol.com
}

\begin{abstract}
This essay examines the role of 'trust' and cooperation in early modern long-distance trade. While most literature on the subject posits trust as a given attribute of long-distance merchant communities and not as a factor in need of historical explanation or analysis, this essay seeks to provide a historical explanation for the creation and role of trust in such communities. It focuses on the history of Armenian merchants from New Julfa, Isfahan, during the seventeenth and eighteenth centuries. The central theoretical model this essay relies upon to explain trust among Julfan Armenian merchants derives from 'social capital' theory as elaborated in sociology and economic sociology, as well as theory from the New Institutional Economics associated with the influential work of Avner Greif. Unlike the latter body of work, however, this essay argues that Julfan trust must be understood not solely as an outcome of informal institutions such as reputation-regulating mechanisms discussed by Greif in his work on Maghribi Jews of the medieval period, but also as a result of the simultaneous combination of both informal and semi-formal legal institutions. In the Julfan context, the essay thus focuses on a merchant arbitrage institution known as the Assembly of Merchants, which enabled Julfan merchants to generate and maintain trust, trustworthiness and uniform norms necessary for collective action and cooperation.
\end{abstract}

\section{Introduction}

Trust was an essential component of early modern long-distance trade, since many essential features of such trade depended upon some modicum of mutual confidence and expectation by one party to a transaction that he would not be defrauded by another as a result of trusting that person in a potentially profitable venture. 'Trust' emerged as a problem because

I would like to thank my dissertation advisers Francesca Trivellato, Rudi Matthee and Nader Sohrabi for their comments and suggestions on an earlier draft of this essay. I also wish to thank Houri Berberian, William Gervase Clarence-Smith, Edmund Herzig, Willem Floor, Claude Markovits and two

anonymous referees of the journal for their helpful comments. 
economic transactions in early modern long-distance trade were rarely based on 'simultaneous exchange'. ${ }^{1}$ The norm was transactions where the quid was separated from the quo over time and space, to paraphrase Avner Greif. ${ }^{2}$ A merchant often did not travel to distant markets with his goods or capital, but delegated this task to an agent. The stationary merchant needed to trust that his agent would not disappear with his capital once he had left his sight. Trust was also vital for merchants who appointed representatives and bestowed upon them powers of attorney in distant places, or loaned out large sums on credit.

Most scholars have merely posited trust as a given attribute of early modern merchant communities, and not as a factor in need of historical explanation or analysis. As Francesca Trivellato has recently noted, the tendency of some scholars to take trust for granted derives from the 'trade diaspora' tradition. ${ }^{3}$ Such scholars have treated trade diasporas as 'communities of mercantile trust', giving the false impression that trust is a natural byproduct of 'closely knit communities'. ${ }^{4}$

This essay seeks to provide a historical explanation for the role of trust and cooperation in the seventeenth- and eighteenth-century trade network of Armenian merchants from New Julfa in modern Iran. 'Social capital theory', borrowed from the social sciences, sheds light on the 'elusive notion of trust'. The Julfan network was characterized by high levels of social capital, inherent in a peculiar social structure, and especially in a semi-formal arbitrage institution known as the 'Assembly of Merchants'. The latter was, arguably, the key factor which enabled Julfan merchants to generate and maintain trust, trustworthiness, and uniform norms necessary for cooperation and collective action.

\section{Trust and social capital}

For Diego Gambetta and Partha Das Gupta, trust is essentially connected with expectations and risk. According to Gambetta, 'when we say we trust someone or that someone is trustworthy, we implicitly mean that the probability that he will perform an action that is beneficial or at least not detrimental to us is high enough for us to consider engaging in some form of cooperation with him'. ${ }^{6}$ Das Gupta further argues that one's expectations of another's course of action are based on the other person's reputation, based on observations of past behaviour. ${ }^{7}$

1 Paul Seabright, The company of strangers: a natural history of economic life, Princeton: Princeton University Press, 2004, p. 48.

2 Avner Greif, Institutions and the path to the modern economy: lessons from medieval trade, Cambridge: Cambridge University Press, 2006, chapter 10.

3 Francesca Trivellato, 'Sephardic merchants in the early modern Atlantic and beyond: toward a comparative historical approach to business cooperation', in Richard L. Kagan and Philip D. Morgan, eds., Atlantic diasporas: Jews, Conversos, and Crypto-Jews in the age of mercantilism, 1500-1800, Baltimore: Johns Hopkins University Press, forthcoming.

4 Ibid.

5 Diego Gambetta, ed., Trust: making and breaking cooperative relations, Oxford: Blackwell, 1988, foreword.

$6 \quad$ Ibid., p. 217.

7 Partha Dasgupta, 'Trust as a commodity', in Gambetta, Trust, p. 54. 
According to Robert Putnam, 'social capital' is defined as 'features of social organizations such as networks, norms and social trust that facilitate coordination and cooperation for mutual benefit'. ${ }^{8}$ Following Ogilvie, social capital is the value generated when individuals join together and invest resources into forming ongoing and structured relationships between themselves (known as a 'social network'), which generate collective and individual benefits. ${ }^{9}$ In addition to a social network, a set of norms is needed, either formal, as in codified and written laws, or informal, as in tacit and habitual norms of conduct internalized by individuals and groups. Information flows within the network disseminate knowledge about norms, and encourage loyalty to them through news of sanctions and rewards. Not only trust but also trustworthiness between network members are created to attain common goals. In early modern merchant communities, social capital reduces transaction costs, that is, 'the costs of measuring and defining the attributes of the goods and services being exchanged and the costs of enforcing agreements with respect to contracts that are made'. ${ }^{10}$

Two factors further help to generate social capital. 'Closure' means that a network has clearly defined borders and set rules limiting membership into the network to individuals who share common values and beliefs. ${ }^{11}$ Closure helps maintain a clearly defined set of norms through 'reputation effects'. ${ }^{12}$ When network membership is clearly defined and information flows through the network, 'members can be easily monitored, normviolating behaviour effectively punished and norm-compliant behaviour collectively rewarded'. ${ }^{13}$ The second condition is 'multiplex' relationships, that is, a network's ability to connect its members to each other through more than one role, position or context. ${ }^{14}$ A network can be characterized as being multiplex if the individuals that comprise it are socially related to each other not only through business ties, but also through membership in the same church, social club, or school system. The denseness of ties establishes memberships that are cross-cutting. In general, 'the denser the network of trading relationships, the greater the value of reputation, and so - for purely self-interested reasons - the greater is the

8 Robert Putnam, 'Tuning in, tuning out: the strange disappearance of social capital in America', PS: Political Science and Politics, 28, 4, 1995, pp. 664-5.

9 Sheilagh Ogilvie, 'The use and abuse of trust: social capital and its development by early modern guilds', Jahrbuch für Wirtschaftsgeschichte, 1, 2005, p. 15.

10 Douglass C. North, 'Institutions, transaction costs and the rise of merchant empires', in James Tracy, ed., The political economy of merchant empires: state power and world trade, Cambridge: Cambridge University Press, 1991, p. 24; Douglass C. North, Institutions, institutional change and economic performance, Cambridge: Cambridge University Press, 1990, chapter 4.

11 James Coleman, 'Social capital in the creation of human capital', American Journal of Sociology 94 (Supplement), pp. $99 \mathrm{ff}$.

12 Avner Greif, 'Reputation and economic institutions in medieval trade: evidences from the Geniza documents', Journal of Economic History, 49, 1989, pp. 857-82.

13 Ogilvie, 'The use and abuse of trust', p. 17.

14 Coleman, 'Social capital', pp. 108-9. The idea is also developed in Mark S. Granovetter's classic essay, 'The strength of weak ties', in American Journal of Sociology, 78, 6, 1973, pp. 1360-80; and his influential 'Economic action and social structure: The problem of embeddedness', American Journal of Sociology, 91, 3, 1985, pp. 481-510. Jeremy Boissevain, Friends of friends: networks, manipulators and coalitions, Oxford: Blackwell, 1974, pp. 34ff., refers to 'many-stranded relations'. 
degree of trust'. ${ }^{15}$ Multi-stranded ties between individuals in a network 'endow members with multiple means of getting information about, punishing deviancies in and urging collective action on one another'. ${ }^{16}$

\section{The Julfan trade network}

New Julfa was a suburb of the Safavid capital of Isfahan, founded in 1605 by silk merchants forcibly displaced by Shah Abbas I from the Armenian town of Old Julfa on the OttomanPersian frontier. They soon expanded into the Russian empire. Astrakhan, on the northern shores of the Caspian Sea, was among their first colonies there, and they were in Moscow and Saint Petersburg by the 1750s, re-invigorating much older Armenian communities in both places. This northward migration of New Julfan merchants was facilitated by a series of treaties signed between the leading families of New Julfa and Tsar Alexevich from 166773, granting special commercial privileges to Julfan merchants. ${ }^{17}$ They also signed trade treaties with Sweden and the Duchy of Kurland (now Latvia). ${ }^{18}$

In the Levant and Mediterranean, an Armenian presence in Aleppo predated the founding of New Julfa by more than a century. ${ }^{19}$ Their most important bridgehead in the west was the Republic of Venice, where Armenian commercial ties went back to the thirteenth century. ${ }^{20}$ Merchants from Old Julfa are recorded in the archives of the city beginning in the 1570s. ${ }^{21}$ In Livorno (Leghorn), New Julfans had become the dominant element of the city's thriving Armenian merchant community by the 1660 s. $^{22}$ Both cities had Armenian churches and were important centres of Armenian printing. Starting in the 1620s, Julfans settled in Marseilles, where their strong commercial presence unleashed harsh protectionist measures that forced them to relocate their businesses to the neighbouring tax-free port of

15 Bruni and Sugden, 'Moral canals: trust and social capital in the work of Hume, Smith and Genovesi', Economics and Philosophy, 16, 2000, pp. 33-4.

16 Ogilvie, 'The use and abuse of trust', p. 17.

17 Shushanik Khachikian, Nor Jughayi Hay vacharakanutiwně ev nra arevtra-tntesakan kaperě russastani het [The Armenian trade of New Julfa and its commercial-economic ties with Russia], Yerevan: Haykakan SSH GA Hratarkchutiun, 1988.

18 Roberto Gulbenkian, 'Philippe de Zagly, marchand arménien de Julfa, et l'établissement du commerce persan en Courland en 1696', in Revue des Études Arméniennes, n.s., 7, 1970, pp. 361-426.

19 Avedis K. Sanjian. The Armenian communities in Syria under Ottoman dominion, Cambridge, MA: Harvard University Press, 1965.

20 Boghos Levon Zekiyan, Le colonie Armene del medio evo in Italia e le relazioni culturali Italo-Armene, Venezia-S. Lazzaro, 1978.

21 Edmund Herzig, 'The rise of the Julfa merchants in the late sixteenth century', in Pembroke Papers 4, 1996, pp. 305-22. See also Sebouh Aslanian, 'From the Indian Ocean to the Mediterranean: Circulation and the global trade networks of Armenian merchants from New Julfa, 1605-1747', forthcoming PhD thesis, Columbia University, New York, chapter 3.

22 See Mesrop Vardapet Oughurlian, Patmutiwn hayots kaghtakanoutean yev Shinutean yekeghetsvo notsa $i$ Livorno kaghaki handerts havelvatsovk [History of Armenian colony of Livorno and the construction of their Church there accompanied with Appendices], Venice: Mechitarist Press, 1891, and Italian translation, Alesandro Orengo, Storia della colonia armena di Livorno Presentazione, traduzione e note di Alessandro Orengo, Livorno: Tipografia O. Debatte, 1991. 
Livorno. $^{23}$ They also settled in Cádiz (Spain), gateway of the Americas, beginning in the $1660 s^{24}$

There were few Julfan Armenian communities in north-western Europe, with Amsterdam as the major exception and London as a late starter. Amsterdam had at least two Armenian churches from 1664 to 1748 and became a centre of Armenian printing in the seventeenth and early eighteenth centuries. ${ }^{25}$ New Julfans were attracted to the city because of the 'strength of Dutch capital' which made it 'possible for [them] to receive prompt payment in cash and to place orders for their return cargos of cloth as soon as they arrived'. ${ }^{26}$ By the 1690s, the most eminent members of Amsterdam's Armenian community were from New Julfa. Surprisingly, despite England's prominence in the East India trade and symbiotic relationship with New Julfan merchants in Iran and India, there was no resident Armenian community in London until the late seventeenth century, when London became home to some forty Armenian merchants, mostly from India and Julfa. At least one prominent Julfa family, the Ghalandarians (known in English records as the Calendar family), had a resident representative in the city. Indeed, it was a member of this family, Khoja Panos Calendar, who signed the famous 1688 'Treaty of East India Company with the Armenian Nation'. ${ }^{27}$

The principal locus of Julfan trade in the East was Mughal India, reached by land and sea from the sixteenth century, and in much larger numbers in the seventeenth century. Arguably, the most important Armenian settlement was Madras, a 'peripheral node' for other settlements in the Indian Ocean. ${ }^{28} \mathrm{~A}$ major factor behind this expansion was the growth of the English East India Company. Though Armenians were trading in India long before the advent of the English and other Europeans, the treaty between the 'Company and the Armenian Nation', signed in London in 1688, acted as a catalyst for Armenian migration from Iran to Mughal India by promising them 'liberty to live in any of the Company's Cities, Garrisons, or Towns in India, and to buy, sell, and purchase Land or Houses, and be capable of all Civil Offices and preferments in the same manner as if they were Englishmen born', and to 'always have the free undisturbed liberty of the exercise of

23 For Marseille, see Charles-Diran Tékéian, Marseille, la Provence et les Arméniens, Marseille: Institut Historique de Provence, 1929; Frederic Macler, 'Notices de manuscrits arméniens ou relatifs aux Arméniens vus dans quelques bibliothèques de la Péninsule Ibérique et du sud-est de la France', in Revue des Études Arméniennes 1, 1920-21, pp. 63-80, 85-116, 237-72, 411-17; 2, 1922, pp. 7-64, 235-91.

24 See Antonio Domínguez Ortiz, 'Armenios en Sevilla' in Archivo Hispalense: Revista Historica, Literaria y Artistica (Sociedad del Archivo Hispalense: Sevilla) 19, 1953, pp. 189-96; Hipolito Sancho de Sopranis, 'Los Armenios en Cádiz' in Seferad: Revista Madrid, 1954, pp. 295-314.

25 See Arakel Sarukhan, Holandan yev Hayere [Holland and the Armenians], Vienna: Mechitarist Press, 1925 .

26 Herzig, 'Venice and the Julfan merchants', in Boghos Levon Zekiyan and Aldo Ferrari, eds., Gli Armeni e Venezia: dagli Sceriman a Mechitar, Il momento culminante di una consuetudine milenaria, Venice: Ist. Veneto di Scienze, Lettere ed. Arti, 2004, p. 160.

27 Ronald Ferrier, 'The agreement of the East India Company with the Armenian nation, 22nd June 1688', Révue des Études Arméniennes n.s., 7, 1970, p. 439. For the larger context of the treaty and its place in British-Armenian relations in the Indian Ocean, See Sebouh Aslanian, "Trade Diaspora versus Colonial State: Armenian Merchants, The English East India Company and the High Court of Admiralty in London, 1748-1752," Diaspora: A Journal of Transnational Studies, 13/1, (spring 2004):37-100.

28 Mesrovb Seth, Armenians in India from the earliest times to the present, 1st edn, Calcutta: n.p., 1937. 
their religion'. ${ }^{29}$ Julfan Armenians also operated out of Burma in the seventeenth century. ${ }^{30}$ They had crossed the Himalayas in the 1660s, to settle in Lhasa (Tibet) where they had a small colony (1660s-1720), whence they conducted trade with the Chinese heartland. ${ }^{31}$ In the first half of the eighteenth century, Julfans had settled in Canton (China). ${ }^{32}$ They were also ensconced in maritime Southeast Asia, including Manila. ${ }^{33}$

\section{The Astrakhan code of law}

Little is known about the origins and development of Julfan commercial law. We know that Julfan merchants had their own body of commercial law at least beginning in the seventeenth century, that this law was not codified in writing, and was most likely customary in nature. The most direct evidence we have of its existence and its statutes comes from the Datastanagirk Astrakhani Hayots, a code of laws used by the Armenian community in Astrakhan, Russia, which enjoyed considerable local autonomy. Armenians had their own independent court (Rathaus) and canon of laws, a Metropolitan See of their Church, and a printing press. ${ }^{34}$ The code was written down for use by the court in the 1760 s, after Russian officials granted the community wide administrative and legal autonomy, thus compelling members of the Rathaus to codify laws for the internal affairs of their community. The greater part of these laws is devoted to commercial affairs. In compiling them, the authors make it abundantly clear that they relied on the commercial law of Julfan merchants. This was scarcely surprising, given that Julfans made up a significant portion of the Astrakhan community.

... for those customs and laws of commerce that we have written down in this manuscript, are especially found among the Armenians who are under the rule of the Persians.... And [those of] our nation who dwell ... in the lands of the Persians have commercial rules and canons which we have followed. ${ }^{35}$

29 Ferrier, 'The agreement', p. 439.

30 Poladian, 'Brmahayk' [Burmese Armenians], in Sion, Amsagir kronakan, grakan, Banasirakan Jerusalem, July-August, 1959, pp. 169-72; Mikayel Gasparian, 'Brmastani Hay gaghut'e' [The Armenian colony of Burma], in Nor Azdarar, Calcutta, 1, 1, 1950, pp. 15-19.

31 See Levon Khachikian, 'The account ledger of merchant Hovhaness of Julfa', Journal of the Asiatic Society, 8, 3, 1966, and the Introduction to Hovhaness Ter Davtean Jughayetsu hashvetumar'e [The accounting ledger of Hovhaness Ter Davtean of Julfa], Yerevan: Haykakan SSH GA Hratarkchutiun, 1984; H. E. Richardson, 'Armenians in India and Tibet', in Journal of the Tibet Society, 1, 1981, pp. 63-7.

32 Derenik Poladian, 'Chinastani Hay vacharakannerě ev Hovhannes Ghazarean' [The Armenian merchants of China and Hovhanes Ghazarian], in Sion, 11-12, 1959, pp. 276-7.

33 Margaret Sarkissian, 'Armenians in South-East Asia', Crossroads, 3, 2-3, 1987, pp. 15-29; Nadia Wright, Respected citizens: the history of Armenians in Singapore and Malaysia, Victoria: Amassia Publishing, 2003; Serafin Quiason, English country trade with the Philippines, 1644-1765, Quezon City: University of Philippines Press, 1966.

34 'Introduction' in F. G. Poghosian, ed., Datastanagirk Astrakhani Hayots [The code of laws of the Astrakhan Armenians], Yerevan: Haykakan SSH GA Hratarkchutiun, 1968. See also A. Yukht, 'Astrakhani Haykakan gaghuti bnakchutyan sotsialakan kazmě 18rt dari arachin kesum', [The social composition of the Armenian population of Astrakhan in the first half of the eighteenth century], Haykakan SSR Gitutyunneri Academyayi Teghekagir, 7, 1957, pp. 47-60; and documents and commentary in George A. Bournoutian, tr. and ed., Armenians and Russia, 1626-1796: a documentary record, Costa Mesa, CA: Mazda Publishers, 2001.

35 Poghosyan, Datastanagirk Astrakhani Hayots, p. 7. 
The authors also make it evident that, though the Julfan Armenians had wide administrative autonomy to conduct themselves in accordance with their own laws except in cases of capital punishment, 'they did not conduct themselves in accordance to codified laws, 36 because they followed the customs of the Iranians, who also did not keep law books but practised law by custom or 'by word'. 37

These passages not only indicate that Julfans had not previously codified their commercial laws, but also suggest that Julfan commercial law was largely based on the prevailing laws of Iran, whether sharia law, decrees of shahs, or customary law. This is understandable, for Julfan merchants were Persian subjects and had been living under Iranian and Muslim influence long before they were resettled in New Julfa. The majority of their legal and mercantile terminology was thus borrowed from Islamic lands. ${ }^{38}$ Overlap between Julfan and Persian commercial terminology can be seen in the following key commercial terms: muzarba (one of the terms for commenda; Arabic mud'araba), vakil (representative with powers of attorney; Persian vakil; Arabic wakil), ruzlama (accounting ledger; Persian ruzname), sanad (Persian and Turkish for bill), amanat (consignment of goods entrusted to an agent; Persian), enalmal (money or credit an agent added to a commenda contract; Persian).

Most of the legal precepts codified in the Astrakhan code were probably also present in Julfa in the seventeenth and eighteenth centuries. Contracts, legal petitions, bills of exchange, and so forth, demonstrate an homology between seventeenth- and eighteenthcentury practices and the code. The section of the code discussing rules for drafting and concluding commenda contracts notes that the party that forwards the capital or goods to the agent keeps anywhere from $70-80 \%$ of the profits accrued from the venture, while the remaining profits go to the agent. That this was part of Julfan commercial law is evident from surviving commenda contracts. ${ }^{39}$ Similarly, the code tells us that a commenda agent was legally bound to follow the advice or orders that his master sent him in a letter of instruction called the ordnagir. ${ }^{40}$ Furthermore, he was obliged to submit a detailed account book of all his transactions to his master soon after returning. 'Every commenda agent is bound to enter each transaction in a lawful account book, truthfully and in time', states Clause 11 of Chapter 14 devoted mostly to commenda law in the code. 'And if a commenda agent fails to show the accounting book to his master, he will be jailed, barely fed on bread and water alone and periodically whipped for a period of up to one year. ${ }^{41}$ The French traveller Jean-Baptiste Tavernier attests to the fact that Julfans in the seventeenth century regarded it as a serious crime for a wayward commenda agent to return home and not render an exact account of his business transactions to his master: 'If they [agents] do not

36 Ibid., p. 6.

37 Poghosyan, Datastanagirk Astrakhani Hayots, p. 6.

38 Edmund Herzig, 'Early modern Armenian commercial law', forthcoming in Kéram Kévonian and Sushil Chaudhury, eds., The Armenians in Asian trade in the seventeenth to eighteenth centuries, Paris, 2006.

39 For a detailed discussion of the Julfan commenda, see Aslanian, 'From the Indian Ocean to the Mediterranean', chapter 7. See also the excellent treatment in Edmund Herzig, 'The Armenian merchants of New Julfa, Isfahan: a study in premodern trade', PhD thesis, Oxford University, 1991, chapter 3 .

40 Datastanagirk Astrakhani Hayots, chapter 14, article 10.

41 Ibid., pp. 132-3. 
thrive, they never return, as being a place where they must give an exact Account, or else suffer the quick and severe Justice of Drubbing, which never fails those factors that are ill husbands for their Masters. ${ }^{42}$

\section{The role of a reputation-based mechanism in Julfan commerce}

To understand the closure of the Julfan network, we must examine relations among Julfan merchants in terms of what Greif calls a 'coalition'. ${ }^{43}$ This is a kind of private club with restrictive membership requirements and mandatory rules of conduct. In the Julfan case, this meant that one had to be a merchant or a commenda agent, in addition to being an Armenian born with lineage in New Julfa, and possibly even ancestry in Old Julfa. Simply being an Armenian merchant did not automatically entitle one to membership in the Julfan coalition. Evidence of the bounded or exclusionary nature of the coalition's identity can be seen in surviving Julfan documents. The evidence suggests that Julfan merchants overwhelmingly cooperated more frequently with fellow Julfans, as opposed to Armenians from other regions. References in Julfan correspondence and contracts to 'one of our own', 'our people' (mer jumiat) or 'our nation of Julfa' are indications that the sense of community invoked in these lines is place- and culture-specific. It refers to individuals with firm family ties to Julfa. It bears remembering here that Julfan Armenians were a 'diaspora within a diaspora' to use Jonathan Israel's terms for Sephardic Jews. ${ }^{44}$ They were distinguished from other Armenians by their shared history and collective trauma of mass exile from Old Julfa, their unique dialect of Armenian (not easily understood by other Armenians), their own peculiar calendar, and, above all, their shared experiences of being citizens of the trading colony of New Julfa. In some cases, Armenian merchants from regions close to New or Old Julfa could also become coalition members. For instance, the Sceriman (Shahrimanian) family of Armenian Catholics operating from Venice had a number of agents and other employees who were originally from the trading town of Agulis (close to Old Julfa), and had close ties to Julfans proper. ${ }^{45}$ But these cases were exceptional.

The second requirement for coalition membership was the tacit agreement among members that they would prefer factors or agents from within the coalition, and would collectively impose sanctions on members who broke established norms. These sanctions could be applied on an ad hoc and informal basis, whereby members ruined the reputation and honour of the guilty party, and thus ensured that other coalition members ceased conducting business with him. Coalition members could distinguish opportunistic members or 'cheaters' from honest reliable ones on the basis of their understanding of Julfan commercial

42 J-B. Tavernier, Collection of travels through Turkey into Persia and the East Indies giving an account of the present state of those countries ..., London: printed for MP (Moses Pitt), 1688, p. 159.

43 Greif, Institutions.

44 Jonathan Israel, Diasporas within a diaspora: Jews, Crypto-Jews and the world of maritime empires 15401740, Leiden: Brill, 2002.

45 For names of Agulis factors, see Sceriman family business letters and account books, in Archivio di Stato di Venezia (henceforth ASV), Documenti Armeni, busta 1, and letter book of Hakob di Murad in ASV, Avogaria di Comun, busta 217. 
law and its norms of proper business behaviour. Trust and cooperation were thus firmly grounded on tacit understanding among coalition members that there would be no tolerance for fellow merchants who broke the network's norms. Being caught cheating would severely compromise one's reputation as a trustworthy merchant and would unleash collective retaliation from fellow coalition members. A bad reputation meant loss of trust and, in some cases, loss of coalition membership, which was tantamount to losing all trading privileges.

It should be noted that, however small, the Julfan coalition was never a 'face-to-face' community. There were probably close to a thousand active members at any given time, making it unlikely (if not impossible) for them to know each other on a personal basis. Given the anonymous or imagined nature of their community, coalition members thus had to base their reputation-based mechanism on the effective and affordable circulation of information inside their network. This was predicated on the existence of a courier network, designed specifically to share vital information among coalition members. The Julfan information network connected commercial communities in the Mediterranean to the nodal centre of Julfa, and through Julfa to settlements in the Indian Ocean. It was relatively efficient, cheap, and fast in delivering news. One vital category of news concerned the business activities and reputations of fellow coalition members. ${ }^{46}$

To avoid being cheated by their agents, merchants involved in long-distance trade decided whether or not to trust certain agents on the basis of past reputation. They therefore 'conditioned future employment on past conduct'. ${ }^{47}$ If an agent had a chequered past and was known to be dishonest, he would lose future prospects of being hired or trusted by other merchants in the coalition, because members of the coalition 'practiced community punishment, and ostracized agents who were considered cheaters until they compensated the injured'. ${ }^{48}$ By circulating information about the reputation of coalition members, commercial correspondence played a crucial role in enabling Julfan merchants to judge whether an agent could be deemed trustworthy, and therefore whether they should conduct business with him. The reputation and trustworthiness of a Julfan merchant were intangible attributes that were nonetheless powerful factors in long-distance trade.

Multi-stranded ties between members also affected the flow of information and the maintenance of norms, and these were produced partly by the Armenian Church, to which most merchants in the coalition belonged. As Julfan merchants branched out into the Indian Ocean, so did the Armenian Church diocese centred in New Julfa, with an elaborate network of diocesan sees in communities where Julfan merchants had settled, especially in India. Eventually, the trade network with its merchants came to overlap and absorb the parallel network of the Armenian Church. This overlapping of Church and merchant networks gave the Julfan trade network a distinctive multiplex structure that played an important role in generating social capital, allowing members to generate high degrees of

46 See Francesca Trivellato, 'Merchants' letters across geographical and social boundaries', in Correspondence and cultural exchange in Europe, 1400-1700, Cambridge: Cambridge University Press, forthcoming. For Julfan correspondence, see Aslanian, “The salt in a merchant's letter": the art of business correspondence, courier networks and their role in Julfan economy and society', in Journal of World History, Winter 2007, forthcoming.

47 Avner Greif, 'Contract enforceability and economic institutions in early trade: the Maghribi traders' coalition', American Economic Review, 133, 3, 1992, p. 530.

48 Ibid., p. 530. 
solidarity and coordinated collective action as a merchant community. Most Julfan merchants had ongoing relations with the Church, not only as faithful and pious members of a flock, but also as generous benefactors, relating and connecting members of the network to each other.

This meant that channels of information were diversified. Instead of receiving news about fellow merchants' activities in India through business correspondence alone, Julfans had access to the grapevine of the Church. Most letters sent from Julfan parish priests in India to their ecclesiastical headquarters at the All Savior's Cathedral in Julfa contained much information on the activities of merchants in the East, patrons and believers, and a considerable part of this information concerned the reputation of merchants. The All Savior's Cathedral in Julfa received regular letters from its missions, and, in turn, spread vital information concerning various merchants in distant settlements to merchant families in Julfa, who would subsequently include such hearsay in their correspondence with fellow merchants and business agents in other settlements. This increased the likelihood that if an individual member of the network broke the network's norms, news of his behaviour would soon reach Julfa, and from there would be spread to other places. ${ }^{49}$ As a result of these multi-stranded ties, members of the Julfan network were better equipped to monitor merchants' behaviour and impose sanctions on violators of norms. Fear of sanctions and of acquiring a bad reputation, of an individual being characterized as binamus, in turn motivated members of the Julfan network to remain honest in their behaviour.

The importance of reputation, or to use the Julfan dialect term akhtibar (from the Persian i'tibar, honour, credit, authority) in Julfan life is revealed in the following passage from a trade manual used as a textbook for training young Julfan merchants in the 1680s:

Do not give money or a consignment [of goods] to an inexperienced man. Even if you know for certain that he is a man of good reputation [akbtibar], ascertain the truth by questioning several people. Only then give him money or credit with a bill [tamasuk] and with witnesses. But [make sure] to write down all your transactions several times. ${ }^{50}$

Merchants generally conducted themselves with remarkable probity because they knew that acquiring a bad reputation was disastrous for their future, as they and their relatives would be sanctioned by the community. As Greif's studies of Maghribi Jewish merchants have demonstrated, maintaining honesty and, therefore, remaining faithful to the network norms of pre-modern merchants had more to do with rationality than religious fear or generalized morality. ${ }^{51}$ In other words, merchants were motivated to conduct themselves with honesty, in relation to fellow merchants of the same network, not necessarily because they

49 A good example of a priest conveying local gossip involving a dispute between two prominent Julfan merchants in Calcutta is in a letter of 1727, in ASCA 'Namakner Bangala 1712-1800', 48. [Letters Bengal, 1712-1800]. For a transcription, see Sebouh Aslanian, 'Hndkahay vacharakanutyan patmut'iunits (XVIII d. skizb)' [From the history of Indo-Armenian trade (beginning of the XVIII century)], PatmaBanasirakan Handes, 171, 1, 2006, pp. 254-71.

50 Constant Jughayetsi, Vasn norahas mankants yev yeritasardats vacharakanats khrat [Concerning advice to the adolescent and to the young merchants] more commonly known as Ashkharazhoghov [General compendium], Ms. 64 Nerses Shnorhali, Library at All Savior's Cathedral, folio 6.

51 Greif, Institutions, chapter 3. 
were inherently moral individuals driven to honesty through religious fear, but also because honesty and respect for a given network's norms were in their rational interest as profitmaximizing individuals. Merchants feared being blotted out of the list of honest and reliable men, that is, blacklisted. As a Julfan merchant writing to his brother in India stated, 'I would rather chuse [sic] to dye [sic], than for them to [blot my] name out of the List. ${ }^{52}$ The same writer reminds his brother that having one's name blotted out of the list in Julfa was 'the same as if you was [sic] a dead man'. The fact that the social network or coalition was closed, and was characterized by multi-stranded relations, made the likelihood of the circulation of rumours and information regarding dishonest behaviour very high. If such rumours regarding the dishonesty of a given merchant spread throughout the network, he would be forced to repair his damaged reputation, in order not to risk being permanently banned from the network as a whole.

Cases of cheating and dishonesty are rarely mentioned in Julfan correspondence. However, those in documents concerning the India trade do raise questions about the effectiveness of information about reputation. Letter-writing did not create full transparency.

The ultimate weakness of the reputation-based informal institution model of trust, associated with the work of Avner Greif, is its inability to be exhaustive. For there to be higher levels of trust, and by extension cooperation between coalition members, a centralized merchant arbitrage institution with some formal attributes needs to exist. The latter would not only demonstrate a credible threat of retaliation in case of malfeasance, but would also be endowed with the institutional means of rendering financial restitution to parties suffering from embezzlement. Such an arbitrage institution did exist in the coalition's nodal centre in Julfa. To understand its nature, its mode of operation and its vital role in creating institutional trust among merchants, we need to look at the autonomous administrative structure of New Julfa as an Armenian trading colony.

\section{The kalantar and the Assembly of Merchants}

Soon after its foundation in 1605 , the Armenian community in New Julfa was granted administrative and legal autonomy under Safavid rule. This autonomy was personified in the office of the kalantar, or mayor of the trading colony. ${ }^{53}$ His responsibilities included collecting taxes, acting as a judge in local affairs, and maintaining public order. ${ }^{54}$ Though this office existed throughout Safavid Iran, its place in Julfan life was unique. The kalantar was always chosen from the local Armenian community, and his appointment seems to have

52 High Court of Admiralty 43-26, High Court of Appeals for Prizes: Papers, Public Records Office (now called National Archives), Santa Catharina logbook of Spanish and English translations, letter no. 147, folios 369-70 (henceforth, HCA, PRO).

53 A. K. S. Lambton, 'The office of kalantar under the Safavids and Afshars', in Mélanges d'orientalisme offerts à Henri Massé, Tehran: Publications de l'Université de Téhéran, 1963, pp. 206-7;

A. K. S. Lambton, 'Cities, i.-iii. Administration and social organization', in Ehsan Yarshater, ed., Encyclopaedia Iranica, 5, 1992, pp. 611-13; and A. K. S. Lambton, 'Kalantar' in Encyclopedia of Islam (Supplement).

54 Lambton, 'The office of kalantar', p. 206. 
resulted from a combination of royal favour, popular election, and a strong hereditary tendency associated with wealth and family prestige. During most of the seventeenth century, a policy of royal appointment of the kalantar from the same wealthy family seems to have been the norm. In the eighteenth century, as central power waned in Persia, the office was filled through popular election, followed by royal ratification. A document from 1751, preserved in the Julfa archives, clearly indicates that the new incumbent to the office of the kalantar, a certain Hovhannes son of Papum, was popularly elected by the entire community of Julfa. ${ }^{55}$ The document also suggests that, after the community had elected their official, a petition was sent to the ruling sovereign asking for royal ratification and investiture.

The same process of community election followed by royal ratification probably existed in the last quarter of the seventeenth century. This is suggested by the rapid turnover rate and the political jockeying in support of different candidates associated with this prestigious office. Seventeenth-century European travel accounts, such as those of Chardin and Tavernier, compare the office of the kalantar to that of a mayor or provost of merchants in Europe. Some accounts also describe the holder of the office as a kind of governor or even a prince ${ }^{56}$ or lord. ${ }^{57}$ Julfans also used the term ishkhan (prince in Armenian) to refer to him. The kalantar was the most important official in the administration of New Julfa. Vladimir Minorsky, commenting on Tad'kirat al Muluk, the famous Safavid manual of administration, notes that 'The Kalantar appointed the Katkhudas, contributed to the repartition of taxes among guilds, formulated the desiderata of the latter, protected the ra'iiyyat (peasants, or lower classes etc.). ${ }^{58}$ The word katkhuda is Persian, meaning district head or leader of a neighbourhood or village.

In the context of New Julfa, katkhudas were individuals who represented and headed the township's twenty districts or neighbourhoods. They were not only in charge of administering their respective districts, but, more importantly, they were members of a special administrative body tasked with running day-to-day affairs in Julfa. As Sh. Khachikian has pointed out, Julfa's katkhudas were members of the suburb's key administrative body known as Vacharakanats zhoghov or Assembly of Merchants, composed of the kalantar and the twenty katkhudas. ${ }^{59}$

The existence of the Assembly of Merchants, as a special administrative and legal body, has been known since the publication of Ter Hovhaneants's two-volume work on

55 The document is in the All Savior's Cathedral Archive in Julfa, Isfahan, (henceforth ASCA) 'Zanazan niwterov grutyunner, 1700-1800. Arevtrakan grutyunner vacharakanneri yev mayrapetneri Amenaprkich ev kusakan vankeri veraberogh', no. 3.

56 The English traveller Thomas Herbert refers to Julfa's second kalantar (Khwaja Nazar) as 'the Armenian prince'. See Thomas Herbert, Some yeares travels into Africa \& Asia the great ..., London: printed by R. Everingham, for R. Scot, T. Basset, J. Wright, and R. Chiswell, 1677, p. 167.

57 Adam Olearius, in the mid-seventeenth century, refers to Kalantar Safraz Beg as an 'Armenian Lord', in The voyages and travels of the ambassadors sent by Frederich Duke of Holstein to the Great Duke of Muscovy, and the King of Persia ..., London: Thomas Dring, 1662, p. 265.

58 Tadhkirat al-muluk: a manual of Safavid administration (circa 1137/1725), Persian text in facsimile BM, Or. 9496) translated and explained by V. Minorsky, London: Luzac and Co., 1943, p. 148.

59 Sh Khachikian, Nor Jughayi hay vacharakanut'yuně, pp. 37-41. See also L Khachikian, 'The account ledger', pp. $176 \mathrm{ff}$. 
the history of Julfa in $1880 .^{60}$ More recent studies are by Levon and Shushanik Khachikian, ${ }^{61}$ and there is a largely derivative commentary by Baghdiantz McCabe. ${ }^{62}$ More recently, Edmund Herzig, in an excellent contribution on Julfan commercial law, has raised doubts about the existence of this Assembly. ${ }^{63}$ Herzig's skepticism is certainly understandable. As he correctly points out, all discussions about this legal or administrative body are based on Ter Hovaneants' work, and rely on it for documentary evidence in support of such an institution. In the absence of further research in the Julfa archives, Herzig concludes, we cannot be certain that this institution actually existed and arbitrated on legal and other affairs. Herzig also assumes that petitions to this body, referred to in Ter Hovaneants' work but not consulted by other scholars, have not survived, because the only catalogue for the Julfa archives does not list such documents separately. ${ }^{64}$

In reality, the Julfa archives contain hundreds of documents sent to this body, as ascertained by the present writer. ${ }^{65}$ Many of them are specifically addressed to the katkhudas and the kalantar of Julfa, and some contain verdicts handed down by this institution. Given the surfeit of archival evidence concerning this institution, we cannot but be certain that this institution existed and played a vital role in the administration of Julfa. This evidence corroborates the contemporary observations on this body by the Dutch traveller Cornelius de Bruin. He visited Julfa in the second half of the seventeenth century and observed that Julfa's kalantar and the kadkhudas administered justice in the settlement. ${ }^{66}$

What we cannot be certain about yet is whether the Assembly of Merchants conducted its affairs in a structured and formalized manner, or if it operated informally according to the tasks at hand. In other words, we do not know whether all twenty katkhudas met to deliberate on each case referred to the Assembly. Examination of seals and signatures found on the petitions to this body suggest that the kalantar's signature and seal, placed on the top-right margin, was always present on petitions, accompanied at the bottom by seals and signatures of some of Julfa's leading merchants. In a few cases, however, a petition examined by the Assembly has all twenty seals of Julfa's katkhudas. A comparison of several petitions dating from the same period (1727 and 1731) reveals that around ten names and seals were consistently present across different petitions, thus suggesting that not all needed to be present to ratify a decision of this

60 Ter Hovhaneants, Harutiwn. Patmutiwn Nor Jughayi (Spahan) [History of New Julfa (Isfahan)], New Julfa: I Tparani Amenaprkchean S. Vanats, 1880-1881. 1st edn.

61 L Khachikian, 'The account ledger', p. 176; Sh. Khachikian, Nor Jughayi hay vacharakanutyun'e, chapter 1.

62 Ina Baghdiantz McCabe, Shah's silk for Europe’s silver, Atlanta: Scholars Press, pp. 93-101. McCabe mainly differs from Khachikian in stating that the Assembly of Merchants was a kind of board of directors for the Julfan 'Trading Company', but provides no evidence.

63 Herzig, 'Early modern Armenian commercial law'.

64 Levon G. Minasian's Diwan N. Jughayi S. Amenap'rkich' vank'i, 1606-1960; ughets'oyts' grgoyk [Archive of the All Savior's Cathedral of New Julfa, 1600-1900: Guidebook], New Julfa: All Savior's Press, 1983.

65 I photographed all the available commercial documents dating from 1595 to 1800 , amounting to about 15,000 images and including petitions to the Assembly of Merchants, in Isfahan in 2005.

66 See Cornelius Le Bruyn, Travels into Muscovy, Persia and part of the East Indies ... Translated from the original French), vol. 1, London: Printed for A. Bettesworth and C. Hitch [et al.], 1738, p. 215. 
body. ${ }^{67}$ This makes sense, since some of the township's katkhuda families would be expected to be away from New Julfa on some occasions. In any case, the evidence suggests that a minimum of some ten to fifteen seals was required to officially ratify a legal decision of the Assembly.

We also do not know how often this body convened, or whether it convened in a specific place, as there is no mention of a special building for such a court. ${ }^{68}$ Similarly, it is not clear whether it met at regular times, or if its meetings were decided on an ad hoc basis, depending on the matter that needed to be addressed. Herzig points out that if such a body did in fact exist, its work was not as structured as Khachikian and, following her, Baghdiantz McCabe suggest. Rather he argues that it must have been an informal institution. ${ }^{69}$ One argument possibly in favour of this view is that the Assembly did not have a codified body of rules, but rather administered an oral law. The evidence suggests that the Assembly's mode of operation was characterized both by informality, lacking written or codified rules or laws and with ad hoc meetings, and some elements of formality, such as being legitimated by the Persian state, and being authorized to impose punishments and sanction offenders against Julfan commercial law.

\section{The Assembly at work: evidence from the documents}

An examination of the petitions stored in the Julfa archives indicates that there were at least two classes of petitions. The first class dealt with strictly commercial matters, such as those arising from certain irregularities in the conduct of commerce both in the suburb and especially in Julfa's overseas colonies. Most of the petitions belonging to this category involve disputes between parties to a commenda contract. Such petitions, addressed to the Assembly of Merchants proper, are formulaically addressed 'To the Master Kalantar, the benevolent district heads and pious merchants'. ${ }^{70}$

Such petitions begin with a summary of the dispute in question, and conclude by beseeching the honourable body to hand down its swift judgment, and some, preserved in the archives of All Savior's Cathedral, also contain the Assembly's decision. These judgments are recorded on the original petition, in the following manner. The kalantar governing at the time records the body's decision on the left margin (horizontal inscription), followed by at least fifteen seals and signatures affirming the kalantar's will at the foot of the document. An analysis of the several petitions that have the Assembly's verdict affixed to them suggests that this body consisted of about twenty to twenty-five individuals, comprising at least ten of the twenty kadkhudas or district heads, representing the twenty

67 A comparison of two petitions to the Assembly of Merchants, both written by the Khwaja Minasian family, dated 1727 and 1731 indicate an overlap of ten signatories in four years with an additional five names introduced in the interval. See ASCA 'Arevtrakan grutyunner vardapetneri kniknerov 1726-1738 zanazan nyuterov grutyunner 5b’ [Commercial documents bearing seals of priests 1726-1738, documents with sundry topics folder $5 \mathrm{~b}]$.

68 Herzig also makes this point in his 'Early modern Armenian commercial law'.

69 Ibid.

70 Petitions dated 1727 and 1731, in ASCA, 'Arevtrakan grutyunner vardapetneri kniknerov 1726-1738 zanazan nyuterov grutyunner $5 \mathrm{~b}$. 
districts of the suburb, and the kalantar. It is noteworthy that church officials are absent from the commercial petitions that have survived in the archives. ${ }^{71}$ Only merchants seem to have been involved in deliberating on secular issues. The kalantar's verdict also appears to have been recorded in accordance with a formulaic convention. It usually begins with the following line: '(I) Kalantar Ohaness along with the community of merchants saw it fit that the following is the verdict of the merchants which I have written below and which must be [fulfilled]. ${ }^{72}$

A second group of petitions relates to legal documents that needed official ratification and legal endorsement. Such documents included powers of attorney, wills and testaments, and papers concerning property deeds involving various individuals or institutions. One of the most distinctive features of such documents is their mode of addressing the Assembly. Unlike the strictly commercial documents mentioned above, they are addressed both to the reigning kalantar and to the archbishop or primate of the time. In other words, they appealed simultaneously to the spiritual and secular authorities of Julfa. This is manifested in the opening lines of the petition where the petitioner declares that at such and such a time he or she appeared before the court (atean) and 'made a confession of an oath before the spiritual and secular fathers of the community'. Apart from the kalantar, the senior religious authorities, the kadkhudas are also addressed. The latter are referred to invariably as 'our strong fortresses of the Armenian community'. The petitioner presents his or her case and ends the petition by stating his or her preparedness in making an appearance before the honourable body to address any concerns. The petition also ends with a formulaic line, in which the petitioner affirms that he or she has made an oath or pronounced the legal formula (segha, from Persian sigheh, legal formula or oath) to the truth of what they have sworn to in Arabic, Persian, and in accordance to the Lord's Prayer of the Armenian Church. ${ }^{73}$

This second class of petitions suggests that there were two closely related but distinct administrative bodies in Julfa. Earlier scholars, seeking to address the administrative aspect of Julfan life, have only discussed the Assembly of Merchants, thus giving the impression that this was the only administrative body present in Julfa. My examination of the petitions stored in the Julfa archives indicates the existence of two separate but interconnected bodies. The first set of petitions (smaller in number) is clearly addressed to the Assembly of Merchants, a body that did not include members of the church. The second set, however, indicates that a larger municipal assembly was also in existence, which, in addition to the kalantar and kadkhudas, included members of the Church hierarchy. This latter body seems to have taken charge of more administrative tasks in Julfa than the more specialized Assembly of Merchants, if the sheer number of petitions addressed to it is any indication. The principal distinction between the two related bodies appears to be that the larger

71 This point is also noted by Khachikian, Nor Jughayi hay vacharakanutyuně, pp. 54-5.

72 The formulaic judgment is recorded on petition, sent to the Assembly by the Khwaja Minasian family and dated Azaria year 112, month of Nadar 12 [29 October 1727] in ASCA 'Arevtrakan grutyunner vardapetneri kniknerov 1726-1738 zanazan nyuterov grutyunner 5b'.

73 Petition dated Azaria year 123 Nadar 30 [16 September 1728] in ASCA 'Arevtrakan grutyunner vardapetneri kniknerov 1726-1738 zanazan nyuterov grutyunner 5b'. Many petitions in ASVA 'Documenti Armeni' have the same expression. The only exceptions are petitions submitted by church officials in Julfa. 
municipal assembly did not hear merchant disputes and did not deliberate on commercial matters, but limited itself to ratifying legal documents.

\section{Portable courts of merchants in the overseas settlements and their relationship to the Assembly of Merchants}

According to Levon Khachikian, many of Julfa's overseas commercial settlements, where sufficient number of Julfans resided, also had a version of the Assembly of Merchants. Khachikian has made a scrupulous analysis of the travel ledger maintained by a Julfan commenda agent, Hovhaness Ter Davtian, who conducted commerce in India, Nepal, and Tibet in the years 1682-93. Even in remote places such as Lhasa or Patna, whenever disputes among Julfan merchants arose, the conflicting parties appealed to the local Julfan community of merchants (the Jumiat) to resolve their differences. In the absence of a sufficient number of Julfan merchants, the Jumiat invited foreign merchants to sit on the board. ${ }^{74}$ Similar procedures were followed throughout the Armenian settlements in India, as well as in Europe. How informal these 'portable courts' were can be seen from a notarial document in the Dutch archives, describing how a dispute between some Julfan merchants and an Armenian printer in the city was resolved at the home of a prominent Julfan merchant named Charriman di Murat (Sceriman di Murat or Shahriman ordi Murati). In this case, the document indicates that the litigating parties met in 1695 with Amsterdam's leading Julfan merchants at the home of the said merchant, and reached an agreement regarding their dispute. ${ }^{75}$ Another document in Julfa dialect, preserved in the Archivio di Stato di Venezia and also dating from the 1690s, similarly indicates that a dispute among some of Venice's Julfan merchants was resolved through convening the local Jumiat. ${ }^{76}$

These portable courts provided members of the Julfan coalition residing or trading in Julfa's overseas settlements with a relatively cheap and effective means of resolving disputes, and thus enabled them to adjudicate community disputes in accordance to Julfan commercial law. Thereby, they did away with the unnecessarily long, costly, and, in some cases, unreliable use of foreign courts, as in the case of Tibet. ${ }^{77}$ Thus if a Julfan merchant in Madras was not paid his loan by a fellow Julfan merchant, he would first and foremost appeal to the Julfan Jumiat in Madras and present his case for arbitrage. If the Jumiat ruled in favour of the plaintiff, they would try to have the defendant pay his loan along with the accumulated interest. If the defendant had already left town, or otherwise refused to pay his debt, the portable court would draft a special notarized document in Julfan dialect, called

74 Khachikian, 'The account ledger', p. 176.

75 Khachikian, Nor Jughayi hay vacharakanutyun'e, p. 52. The notarial document referring to this dispute and its resolution is translated and discussed in Sarukhan, Hollandan yev hayer'e, pp. 104-5 and Mesrop Gregorian, Nor Niuter yev ditoghutyunner hratarakich Vanantetsvoh masin [New materials and observations on the Vanantetsi family of publishers], Vienna: Mekhitarist Press, 1966, pp. 48-9.

76 ASV, 'Documenti Armeni', busta 1. The document is dated 15 April 1697 [Gregorian calendar] and is briefly discussed in Herzig, 'Early modern Armenian commercial law'. See appendix of Aslanian 'From the Indian Ocean to the Mediterranean', for a translation and discussion of the document.

Khachikian, 'The account ledger', p. 177. 
a manzara (Persian mazhar, meaning document attested by witnesses, attestation, testimony). ${ }^{78}$ They would send this document, along with supporting evidence, to the Assembly of Merchants in Julfa. ${ }^{79}$ The Assembly would review the case. If they ruled on the plaintiff's behalf, they would pressure the defendant, if he happened to be in Julfa at the time, or family members, to repay the debt.

This relationship between the portable courts in the settlements and the Assembly of Merchants in Julfa was arguably the single most important institutional feature in Julfan society when it came to monitoring and sanctioning opportunistic behaviour, be it in Julfa itself or in its settlements in India or the Mediterranean. There are dozens of manzaras and other notarized documents, sent to the Assembly of Merchants from portable courts in Julfan settlements in such places as Paris, Livorno, Venice, Madras, and Hyderabad. This indicates that links between the Assembly of Merchants in Julfa and its offshoot courts in the settlements were active and important ones. The documents indicate that the Assembly was the ultimate court of appeal for intra-Julfan disputes that could not be resolved in situ overseas. They also indicate that the Assembly imposed effective sanctions on merchants who were deemed to have broken the coalition's norms. However, just how the Assembly enforced such sanctions is not clearly indicated in the surviving documents. We know that the Assembly often compelled the guilty party's family or relatives to right a wrong, and probably also used boycotting and shaming as a tactic to bring the guilty party into line. ${ }^{80}$

It seems that, in addition to its juridical and arbitration activities, the Assembly of Merchants in Julfa was a centralized information clearing house. Information, in the form of notarized contracts, powers of attorney, petitions and correspondence between litigants to the Assembly reached Julfa from coalition members working in overseas settlements. News, in the form of gossip about merchants overseas, their business activities, and their reputations, would then be leaked to members of Julfa's resident merchant families either through the kalantar or through one of the katkhudas. Members of Julfa's merchant families disseminated the news through business correspondence to their agents or associates overseas. An example of how this happened is found in a 1746 letter by a Julfan merchant named Raffael di Hagalar in Julfa to his associate Khwaja Minas di Elias in Calcutta, India. In his letter, Raffael refers to a Julfan merchant in Madras named Sultanum who had problems paying debts to creditors back in Julfa. 'I do observe,' writes Raffael in his business letter, 'that Mr Sultanum has not paid the Bill of Exchange. I know this because the same has been sent back. And though Mr Hagamal is [of the] opinion that the money is as safe as if the same was in the Bank, for my part I look on the said Money as wholly lost. ${ }^{, 81}$ The bill of exchange alluded to in Raffael's letter, was a manzara, accompanied by the original bill of exchange sent by the Jumiat's portable court in Madras to the Assembly of Merchants in Julfa.

78 Francis Joseph Steingass, A comprehensive Persian-English dictionary, including the Arabic words and phrases to be met with in Persian literature, London: Routledge \& Kegan Paul, 1892, p. 1187.

79 Khachikian, Nor Jughayi Hay vacharakanutyun'e, p. 177. See also Herzig, 'The commercial law', and Baghdiantz McCabe, Shah's silk, p. 233.

80 For a case of 'shaming' see letter no. 1428 in HCA 30/682 Ship's papers (Santa Catharina), PRO London.

81 Letter no. 55 Santa Catharina ship's papers, HCA/42-026, Spanish and English translations of ship's papers, log book, folio 180, PRO London. 
It is interesting to note that Raffael had heard about Sultanum's 'bounced cheque' through the members of the Assembly, and conveyed this hearsay along with other gossip about Sultanum's ordeals in India and Julfa to his associate in Calcutta, to alert him of Sultanum's declining reputation. This and other evidence suggests that, along with the Church hierarchy at All Savior's Cathedral in Julfa, the Assembly of Merchants was another 'connectivity node' that imbued the Julfan network with the kind of multi-stranded ties that made information flow faster and more extensively throughout the network. In this respect, the Assembly's role in the flow of information through the network can be compared to a bandwidth in a transistor radio, with multiple frequencies. The fact that the Assembly was linked to the portable courts in the settlements enabled it to accumulate information in the form of legal petitions, notarized papers, or just correspondence containing business gossip. One example of this commercial hearsay is found in a petition to the Assembly of Merchants dated 6 September 1697. In this case, a Julfan merchant in Chinapatan (Madras), named Vatan, was defrauded by one of his agents, named Mattos di Panos, who had taken loans in Madras and Bengal in his master's name and fled town without paying his debts. ${ }^{82}$ After many futile attempts to contact his opportunistic agent and plead with him to restore the huge debts he had left to his master, Vatan was forced to appeal to the Jumiat in Madras. The portable court had then notarized one of the long letters sent by Vatan to his agent, along with two petitions written by Vatan regarding the fraudulent activities of Mattos, and sent them as manzaras to the Assembly of Merchants. The Jumiat asked the Assembly to arrest the fraudulent agent if he happened to be in Julfa, or to disseminate news about his behaviour and compel him to return to Julfa to restore his debt to representatives Vatan had dispatched to Julfa to receive his money.

As this example illustrates, wronged parties called on the Assembly to intervene legally and punish coalition members who were regarded as having broken the norms of the network. The case also illustrates that, in addition to passing judgment and ordering the restitution of money owed to honest merchants, the Assembly also stored vast quantities of information received from its portable courts in overseas settlements. Such information might not have been available to individual coalition merchants, with a more limited network of relations. The Assembly then pumped back this vital information into the network by 'leaking' to merchants in Julfa, who in turn circulated the information to their agents and business correspondents in faraway places. As a result, the Assembly of Merchants was able to supplement the flow of information in Julfan business correspondence and more effectively broadcast vital information to coalition members that might escape the notice of individual merchants and their networks of business correspondents. Without the grapevine of the Assembly, the reputation-related information available to ordinary members of the coalition would have been limited to information provided by business partners or commenda agents, or by Church sources.

82 The documents about this fleeced merchant are preserved in ASCA, folder 'Namakner Chinipatanits' [Letters from Chinapatan], document dated year 1146 of the Greater Armenian Calendar, Nadar 20 or September 6, 1697. The date of 1711 ascribed to the document by the archivist (Levon Minasian) is patently wrong. See appendix of Aslanian, 'From the Indian Ocean to the Mediterranean' for a translation and gloss of this document. 


\section{Agents and cross-cultural relations}

The closed and multiplex nature of the Julfan coalition raises an important question about cross-cultural economic relations. Trivellato's work breaks new ground in pointing out that much of the trade diaspora literature has narrowly focused on intra-group dynamics, whereas Trivellato explores ways in which trade diaspora communities commercially interacted and collaborated with other trade diasporas. She has also challenged Greif's premise that merchants restricted their trust-sensitive market transactions to members of their own community. ${ }^{83}$ While much of Greif's work may be too narrowly confined to Maghribi Jewish merchants and their intra-community relations, his analysis of those relations remains convincing.

The Julfans did trade outside their coalition, but the evidence suggests that, like Greif's Maghribi Jews, they restricted hiring of agents to their coalition. The evidence does not show a single case of a non-coalition member hired by Julfans as an agent or factor. Indeed, there are even very few non-Julfan Armenians. This happened for two reasons. First, the reputation-based informal institution and the legally-based semi-formal institution could not provide adequate mechanisms of monitoring trust outside the coalition, a critical issue in cross-cultural relations of trust. This provides a rational and non-cultural explanation for why some ethno-religiously defined and stateless merchant communities, such as Julfan Armenians and Maghribi Jews, tended to perpetuate themselves as culturally inclusive and cohesive communities. Without reducing culture and identity to practical rational choice, one can still argue that it was rational for Julfans to remain loyal to their coalition, and in doing so to reproduce their community as a culturally defined and closed social network. Maintaining a Julfan Armenian identity was, in part, an economic concern that had more to do with generating social capital to compensate for other kinds of capital (political or military) that stateless Julfans did not possess, than with religious or cultural injunctions to maintain a distinct identity.

This does not mean that Julfans did not interact economically with non-Julfans or with non-Armenians. They borrowed funds from Indian shroffs (sarrafs or money lenders) in Isfahan, as some bills of exchange known as hundis stored in the Archives of Venice and New Julfa or Isfahan demonstrate. ${ }^{84}$ They also sold merchandize to outsiders, and bought some from them. But these activities were very different from agency-related activities. Agency-related cooperation represents a high security issue, different from all other activities mentioned above, so that trust becomes a special problem predominantly with agency transactions. As far as different levels of trust are concerned, transactions related to commenda contracts represent a sphere of economic activity where one would expect to find the highest levels of trust and trustworthiness, followed by those involving the bestowing of powers of attorney and those concerning the appointment of executors in last wills and testaments. In all three cases, the evidence overwhelmingly indicates that Julfans transacted exclusively with fellow coalition members, in interactions characterized by high levels

83 Francesca Trivellato, 'Juifs de Livourne, Italiens de Lisbonne, Hindous de Goa. Réseaux marchands et échanges interculturels à l'époque moderne', Annales: Économies, Sociétés, Civilisations, May-June 2003, pp. 581-603; Trivellato, 'Sephardic merchants'.

84 A hundi stored in the Archivio di Stato di Venezia is translated and reproduced in facsimile as document 2 in Herzig, 'The Armenian merchants of New Julfa', pp. 293-8. 
of trust. In the handful of cases where foreigners acted as executors for Julfan wills, there were few Julfans in the places where such wills were drafted. ${ }^{85}$ Powers of attorney all involved fellow Julfans, most of them relatives or sons of reputable families.

\section{Conclusion}

The arguments about social capital and trust in general, and about their role in Julfan commerce, permit the following conclusions. First, it seems that for trust as social capital to exist, it helps for a social network to have two overriding properties. The argument for closure or denseness fits well with Greif's notion of 'coalition'. A closed and multiplex network, or a coalition with strict membership rules, allows for easier and cheaper social monitoring, based on better information flows, better enforcement of social norms and more effective application of sanctions on offenders, as well as rewards for those who comply with the norms. All this is crucial for communities of long-distance trade because it increases cooperation and solidarity, reduces transaction costs, and gives them an edge over others without these advantages. An excellent example of such a network is the ultra-Orthodox Jewish community of diamond merchants based in Brooklyn. ${ }^{86}$ My analysis suggests that early modern Julfan Armenian merchants operated like their Jewish counterparts in New York City today, even if their network was not circumscribed to a few neighbourhoods in Brooklyn and a tiny district in midtown Manhattan.

Second, keeping the Julfan coalition or social network closed and numerically small was a built-in and rational feature of the organizational basis of Julfan trade. In other words, an argument can be made that Julfan identity was not solely or predominantly driven by cultural concerns or influences, centred on the Church, as much of the Armenian language, nationalist-inspired literature on Julfa would have us believe. The rational economic needs built into the Julfan network also played a significant role in shaping Julfan identity. The network analysis, inspired by social capital theory, indicates that large networks with porous boundaries decrease trust and trustworthiness, increasing transaction costs for network members. This provides a rational incentive for network members to keep their network down to a manageable size, and to ensure that its boundaries remain closed through persistent policing and monitoring. In other words, for the average Julfan merchant, maintaining his communal affiliation, and thereby perpetuating the social identity of the network, was a rationally motivated choice. ${ }^{87}$

\section{Sebouh Aslanian is currently a visiting lecturer at the Department of History, Claremont McKenna College, California.}

85 Examination of hundreds of wills stored in the Julfa archives has revealed only one Portuguese executor for a Julfan will drawn up in Canton, and one Spaniard for a will written in Manila. See ASCA folder: 'Zanazan nyuterov grutyunner 28/4: Cantom [sic] ktak' [Papers with sundry topics, Canton, Will] dated 1794. For the Manila will see the reference in a commercial letter stored in HCA-42-026, Santa Catharina logbook of Spanish and English translations, letter no. 9, folio 26.

86 Lisa Bernstein, 'Opting out of the legal system: extralegal contractual relations in the diamond industry', Journal of Legal Studies, 21, 1, 1992, pp. 115-57.

87 For the Maghribi case, see Greif, Institutions, p. 59. 